Volume 6 Nomor 1, Januari - April 2020, halaman 12 - 24

Tersedia Daring pada http://jurnal.stkipbjm.ac.id/index.php/math

\title{
PROFIL PEMECAHAN MASALAH SISWA SMP DALAM MENYELESAIKAN SOAL TIMSS KONTEN ALJABAR BERDASARKAN PEMECAHAN MASALAH IDEAL
}

\section{THE PROFILE OF JUNIOR HIGH SCHOOL STUDENTS' PROBLEM SOLVING IN ANSWERING THE CONTENT TIMSS TEST OF ALGEBRA ON IDEAL PROBLEM SOLVING}

\author{
Maria Krissanti, Tri Nova Hasti Yunianta \\ Universitas Kristen Satya Wacana
}

202016026@student.uksw.edu, trinova.yunianta@uksw.edu

\begin{abstract}
Abstrak: Penelitian ini bertujuan untuk mengetahui profil pemecahan masalah siswa dalam menyelesaikan soal TIMSS konten aljabar berdasarkan pemecahan masalah IDEAL (I-Identify problem, D-Define goals, E-Explore possible strategies, A-Anticipate outcomes and act, dan L-Look back and learn) pada siswa kelas VIII di SMP Kristen 2 Salatiga. Penelitian ini merupakan penelitian kualitatif. Terdapat 3 soal pilihan ganda TIMSS konten aljabar dengan topik pola, bentuk aljabar, serta persamaan dan fungsi. Pemilihan subjek dalam penelitian ini dengan menggunakan purposive sampling yang diperoleh sebanyak 3 subjek. Teknik pengumpulan data yang digunakan adalah tes, wawancara, dan dokumentasi. Analisis data yang digunakan yaitu indikator pemecahan masalah IDEAL. Berdasarkan hasil tes dan wawancara, menunjukkan bahwa sebagian subjek telah mampu melakukan tahapan-tahapan pemecahan masalah dengan tepat dan runtut, namun sebagian subjek juga cenderung kurang dalam tahap Explore possible strategies dan tahap Look back and learn.
\end{abstract}

Kata Kunci: pemecahan masalah IDEAL, soal matematika TIMSS, aljabar

Abstract: This research aims to determine the profile of students' problem solving in solving TIMSS algebraic content based on IDEAL problem solving (I-Identify problems, D-Define goals, E-Explore possible strategies, AAnticipate outcomes and actions, and L-Look back and learn) in class VIII students at Christian Middle School 2 Salatiga. This research is a qualitative research. There are 3 multiple choice questions TIMSS algebra content with the topic of patterns, forms of algebra, as well as equations and functions. The selection of subjects in this study using purposive sampling obtained as many as 3 subjects. Data collection techniques used were tests, interviews, and documentation. Analysis of the data used is the IDEAL problem solving indicator Based on the results of tests and interviews, it shows that some subjects have been able to carry out the stages of problem solving appropriately and coherently, but some subjects are also lacking in the Explore possible strategies and Look back and learn stages.

Keywords: IDEAL problem solving, TIMSS mathematical problem, algebra

Cara Sitasi: Krissanti, M., \& Yunianta, T. N. H., (2020). Profil pemecahan masalah siswa SMP dalam menyelesaikan soal TIMSS konten aljabar berdasarkan pemecahan masalah IDEAL. Math Didactic: Jurnal Pendidikan Matematika, 6(1), 12-24. https://doi.org/10.33654/math.v6i1.853

Submitted: December 8, 2019

Revised: April 9, 2020

Published: April 30, 2020

Available Online Since: April 10, 2020 
Salah satu kegiatan yang mengukur kemampuan siswa di bidang matematika dan sains dalam suatu negara melalui survei internasional yang disebut dengan Trends in International Mathematics and Science Study (TIMSS). TIMSS merupakan suatu studi internasional yang cenderung mengarah pada perkembangan dalam ruang lingkup matematika dan sains (Widayanti \& Kolbi, 2018). The International Association for the Evaluation of Educational Achievement (IEA) adalah asosiasi internasional yang menyelenggarakan studi tersebut yang bertujuan untuk menilai suatu prestasi dalam pendidikan. Lynch School of Education, Boston College, USA ialah tempat berpusatnya TIMSS. Peringkat Indonesia dalam TIMSS dibidang matematika menduduki peringkat 36 dari 49 negara pada tahun 2007. Lalu pada tahun 2011 dari hasil TIMSS, Indonesia menduduki peringkat 38 dari 42 negara (Cahyono \& Adilah, 2016). Setelah itu pada tahun 2015 dari hasil TIMSS, Indonesia menduduki peringkat 44 dari 49 negara. Hal tersebut sejalan dengan penelitian Sidauruk \& Ratu (2018) yang menyatakan bahwa nilai matematika siswa di Indonesia dalam TIMSS semakin menurun.

TIMSS terdiri dari dua domain yaitu domain konten dan domain kognitif (Susanti, 2016). Domain konten terdiri beberapa materi yaitu bilangan, aljabar, bentuk geometri, peluang dan data. Selain domain konten juga ada domain kognitif yang terdiri dari pengetahuan, penerapan, dan penalaran. Pengetahuan pada domain kognitif mencakup fakta-fakta tentang matematika atau sains, konsep dan prosedur yang dapat dipahami dengan mudah oleh siswa. Penerapan pada domain kognitif adalah suatu kemampuan siswa yang berfokus dalam menentukan dan menerapkan berbagai pengetahuan yang telah dipelajari serta pemahaman mengenai konsep untuk menyelesaikan masalah. Sedangkan penalaran dalam domain kognitif adalah suatu penyelesaian yang lebih berfokus pada penyelesaian masalah non rutin.

Siswa merasa kesulitan dan memiliki pemahaman yang masih rendah mengenai konsep - konsep tentang operasi bentuk aljabar. Kesulitan siswa tersebut mendapat perhatian khusus karena berdampak pada rendahnya pemahaman mengenai konsep, aturan dan fakta serta prosedur tentang aljabar (Sidauruk \& Ratu, 2018). Hal tersebut juga telah diungkapkan berdasarkan hasil kajian dalam permasalahan kontekstual mengenalkan bentuk aljabar di SMP. Dalam hal ini, siswa diharapkan untuk dapat memahami, menjelaskan dan mengaplikasikannya dalam pemecahan masalah mengenai konsep matematika (Rudhito \& Prasetyo, 2016).

Pemecahan masalah menurut Dahar (1989) merupakan suatu kegiatan yang dilakukan manusia dalam menggabungkan konsep-konsep bahkan aturan-aturan yang telah diperoleh sebelumnya, dan tidak sebagai suatu keterampilan generik. Hal tersebut sejalan dengan penelitian Sidauruk \& Ratu (2018) yang menyatakan bahwa pemecahan masalah di bidang matematika melibatkan banyak metode yang tidak standar dan tidak diketahui terlebih dahulu bagaimana cara menyelesaikannya. Penyelesaiannya yaitu siswa harus lebih menggunakan atau memanfaatkan pengetahuan yang dimilikinya, sehingga melalui proses seperti ini mereka akan lebih sering mengembangkan pemahaman baru mengenai matematika. Maka dari itu pemecahan masalah merupakan bagian yang sangat penting, karena dalam proses pembelajaran penyelesaian memungkinkan siswa untuk dapat memperoleh pengalaman dengan menggunakan pengetahuan serta 
keterampilan yang sudah dimiliki untuk diterapkan pada masalah yang bersifat tidak rutin (Susiana, 2010).

Berbagai pemecahan masalah yang dapat digunakan untuk menyelesaikan suatu masalah dalam matematika, salah satunya yaitu dengan menggunakan model pemecahan masalah IDEAL yang dapat digunakan untuk mengatasi lemahnya kemampuan siswa dalam pemecahan masalah (Damayanti \& Yunianta, 2018). Menurut Bransford \& Stein (1984) bahwa solusi pemecahan masalah IDEAL memiliki langkah-langkah sebagai berikut: (1) identify the problem (mengidentifikasi masalah); (2) define goals (mendefinisikan tujuan); (3) Explore possible strategies (mengeksplorasi rencana yang mungkin); (4) anticipate outcomes and act (mengantisipasi hasil dan tindakan); (5) Look back and learning (melihat dan belajar). Model pemecahan masalah IDEAL merupakan suatu kegiatan pembelajaran yang dapat membantu siswa dalam menyelesaikan masalah yang bertujuan untuk meningkatkan pemahaman pada siswa tentang materi pembelajaran dengan cara konseptual dan prosedural (Yanti \& Syazali, 2016). Mengacu pada penelitian Purnomo \& Mawarsari (2014) yang menyatakan bahwa pelaksanaan pemecahan masalah IDEAL memiliki dampak yang positif dalam meningkatkan kemampuan masalah pemecahan masalah. Pemecahan masalah IDEAL dapat digunakan sebagai cara agar siswa dapat menyelesaikan masalah atau soal yang terdefinisi dengan baik (Nayazik, 2017). Hal ini sejalan dengan penelitian Annizar (2015) yang berpendapat bahwa pemecahan masalah IDEAL dipilih karena pemecahan masalah IDEAL ini lebih rinci dari pemecahan masalah sebelumnya seperti Polya, di mana tahap identifikasi masalah dan tahap menentukan tujuan masalah dibuat menjadi satu tahap sementara pada pemecahan masalah IDEAL dibuat menjadi dua tahap. Tahapan pemecahan masalah IDEAL dapat dilihat pada bagan 1.

Berdasarkan uraian di atas, maka dapat disimpulkan betapa pentingnya untuk dapat mengetahui profil pemecahan masalah pada siswa SMP dengan menggunakan materi aljabar. Penelitian ini menggunakan soal-soal TIMSS konten aljabar. Oleh karena itu, permasalahan dalam penelitian ini dapat dirumuskan yaitu bagaimana profil pemecahan masalah soal TIMSS konten aljabar berdasarkan pemecahan masalah IDEAL.

\section{Metode Penelitian}

Jenis penelitian yang digunakan dalam penelitian ini adalah penelitian kualitatif. Menurut Sugiyono (2015) penelitian kualitatif merupakan suatu metode dengan berlandaskan pada filsafat post positivism, yang dapat digunakan untuk meneliti suatu kondisi dalam obyek alamiah. Subjek pada penelitian ini adalah 3 siswa kelas VIII C SMP Kristen 2 Salatiga yang telah memperoleh materi Aljabar. Teknik pengambilan subjek dalam penelitian ini adalah dengan cara purposive sampling yaitu teknik pengambilan subjek dipilih dengan kriteria tertentu (Sugiyono, 2015). Pertimbangan pemilihan subjek yang digunakan dalam penelitian ini adalah siswa berkemampuan tinggi yang dapat dilihat dari nilai rapor matematika kelas VII dan pengamatan dari guru matematika selama proses pembelajaran matematika, dapat bekerja sama dengan peneliti untuk terlibat dalam penelitian, memiliki kemampuan komunikasi yang baik secara lisan maupun tulisan. Soal yang digunakan dalam penelitian ini terdiri dari 3 soal pilihan ganda yang diambil dari Framework TIMSS konten 
aljabar dengan topik pola, bentuk aljabar, serta persamaan dan fungsi dengan maksimal waktu mengerjakan 25 menit. Keabsahan data yang dilakukan dalam penelitian ini dengan menggunakan cara triangulasi teknik. Triangulasi teknik adalah menguji kredibilitas data dilakukan dengan cara mengecek data yang sama kepada sumber yang sama dengan teknik yang berbeda dengan melakukan observasi, wawancara dan dokumentasi (Sugiyono, 2015). Analisis data untuk mengetahui pemecahan masalah yang digunakan subjek dengan menggunakan indikator dan pedoman wawancara berdasarkan pemecahan masalah IDEAL yang dapat dilihat pada Bagan 1.

\section{Bagan 1. Tahapan IDEAL}

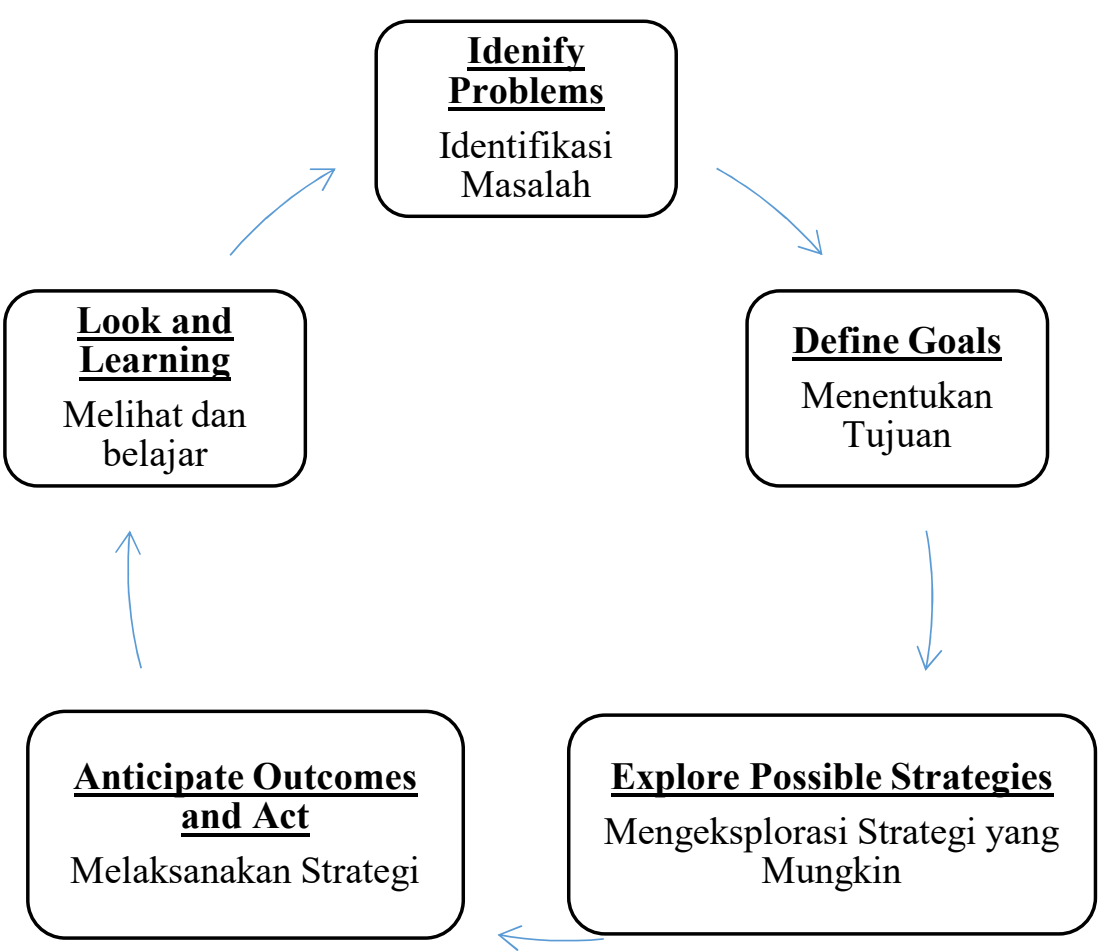

Hasil Penelitian dan Pembahasan

\section{Hasil}

A. Nomor 1 (Topik Pola) 
Pat mempunyai ubin merah dan ubin hitam. Pat ingin menggunakan ubin tersebut untuk membuat bentuk persegi.

Bentuk $3 \times 3$ memiliki 1 ubin hitam dan 8 ubin

Bentuk $4 \times 4$ memiliki 4 ubin hitam merah

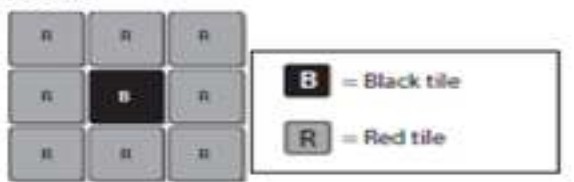
dan 12 ubin merah

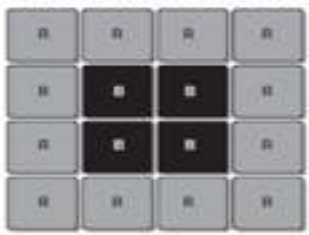

Jika Pat ingin membuat bentuk $9 \times 9$, maka berapa jumlah ubin hitam dan jumlah ubin merah?

A. 49 ubin hitam and 32 ubin merah

B. 64 ubin hitam and 17 ubin merah

C. 47 ubin hitam and 34 ubin merah

D. 34 ubin hitam and 47 ubin merah

Gambar 1. Soal nomor 1 (topik pola)

1. Diketahui: ingin membuat bentuk $9 \times 9$

tanya: jmlh ubin hitam dan julh ubin meroh?

Ester Devina A.H.

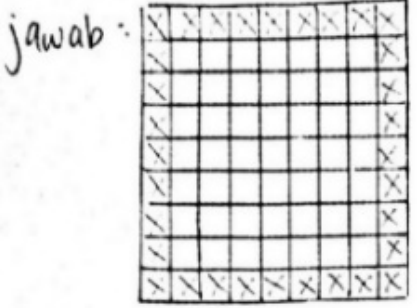

ket: $⿴$ ubin merah

u ubin hitam

$\rightarrow 9+9+7+7\}$ ubin merah

$=32$

$8 C$

ubin hitam $=9 \times 9=81-3$ ?

$: 49$

Gambar 2. Hasil jawaban subjek S1 dalam menjawab soal nomor 1

Shanna

$8 C / 17$

SMP Krisdusa

1. Diket: Pot mempunyai ubin merah don hitom

Bentuk $3 \times 3$ memiliki 1 ubin hitam 18 ubin merah

Bentuk $4 \times 4-11-4$ ulin hitam $\$ 12$ ubin merah

Ditanya : Bentuk $9 \times 9$ ?

Jawab: $3 \times 3 \rightarrow 1$ ubin hitam \& 8 ubin merah

$4 \times 4 \rightarrow 4$ ubin hitam $\times 12$ ubin merah

$5 \times 5 \rightarrow 9$ ubin hitam 116 ubin merah

$6 \times 6 \rightarrow 16$ ubin hitam $\& 20$ ubin merah

$7 \times 7 \rightarrow 25$ ubin hitam $\& 24$ ubin merah

$8 \times 8 \rightarrow 36$ voin hitam $\& 28$ ubin merah

$9 \times 9 \rightarrow 49$ ubin hitam \& 32 ubin merah

setrap ubin merah selisih 4

Ubin hitam $\rightarrow$ bilangan ganjil.

atau bentuk - ubin merah.

Jadi, Jumlah ubin hitam dan ubin merah $9 \times 9$ adalah 49 ubin hitam dan 32 ubin madel

Gambar 3. Hasil jawaban subjek S2 dalam menjawab soal nomor 1 
1 Diket= $3 \times 3=1$ hitam 8 merah

Tanya $=9 \times g=$ ?

Lawjab $=9 \times 9$ adalah sisixsisi, Jika sisi atasnya panjangnya 9 dan sisi bawch panjangnga 9 maka sisi surnfingnya dikurangi a balok
Jadi, ubin merah $=9+9+7+7=32$

ulen hitam: luas - ukin merah

$$
=81-32=49
$$

Gambar 4. Hasil jawaban subjek S3 dalam menjawab soal nomor 1

Pada topik pola, Subjek S1 dan S2 telah melakukan tahap identifikasi masalah, tahap menentukan tujuan dan tahap melaksanakan strategi. Keduanya tidak melakukan tahap mengeksplorasi strategi dan tahap melihat dan belajar. Subjek S3 telah melakukan tahap identifikasi masalah, tahap menentukan tujuan dan tahap melaksanakan strategi, serta tahap melihat dan belajar. Subjek S3 tidak melakukan tahap mengeksplorasi strategi.

B. Nomor 2 (Topik Bentuk Aljabar)

\begin{tabular}{|l|l|}
\hline \multicolumn{1}{|l|}{ Bentuk di atas adalah persegi panjang, dengan panjang $l}$, \\
dan lebar $w$. Jika panjangnya dibuat dua kali lipat dan \\
lebarnya tetap sama, rumus mana yang menyatakan Luas \\
(L) dari persegi Panjang yang baru? \\
A. $L=2 l+2 w$ \\
B. $L=2 l+4 w$ \\
C. $L=2 l w$ \\
D. $L=4 l w$
\end{tabular}

Gambar 5. Soal nomor 2 (Topik Bentuk Aljabar)



Gambar 6. Hasil jawaban subjek S1 dalam menjawab soal nomor 2 
2. Diket: Persegi panjang dengan panjang $\ell$ dan lebar $w$. Panjang $2 \times$ lipatnya dan lebarnya tetap sama.

Ditanya: Rumus mana yg menyatakan Luas $(L)$ dari persegi panjang yg baru?

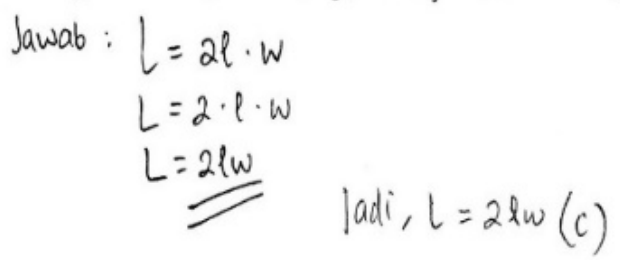

Gambar 7. Hasil jawaban subjek S2 dalam menjawab soal nomor 2

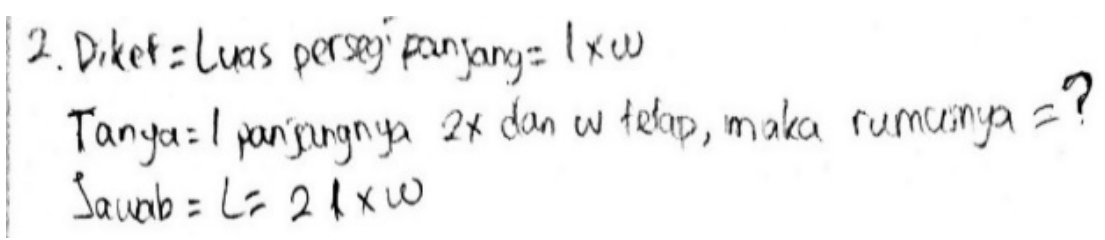

Gambar 8. Hasil jawaban subjek S3 dalam menjawab soal nomor 2

Pada topik bentuk aljabar, Subjek S1, S2, dan S3 telah melakukan tahap identifikasi masalah, tahap menentukan tujuan dan tahap melaksanakan strategi. Ketiganya tidak melakukan tahap mengeksplorasi strategi dan tahap melihat dan belajar.

\section{Nomor 3 (Topik Persamaan dan Fungsi)}

Jo memiliki tiga logam balok. Berat masing-masing balok adalah sama.

Ketika dia menimbang satu balok terhadap berat 8 gram, inilah yang terjadi

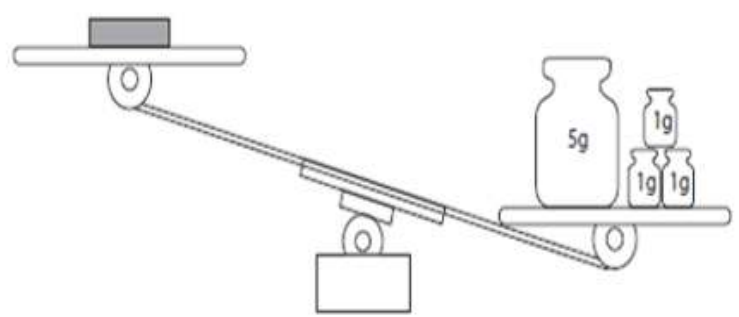

Ketika dia menimbang ketiga logam balok dengan berat 20 gram, inilah yang terjadi

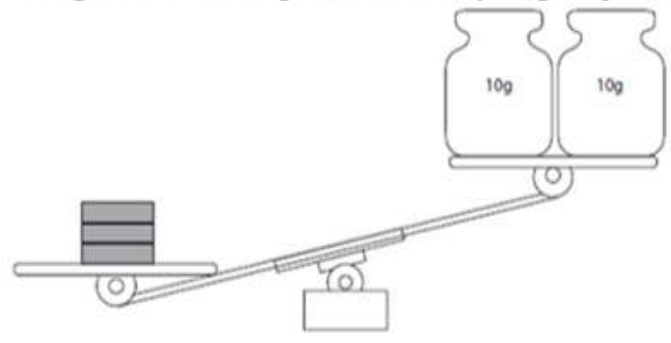

Manakah dari pilihan berikut ini yang bisa menyatakan berat satu logam balok?
A. 5 gram
C. 7 gram
B. 6 gram
D. 8 gram

\section{Gambar 9. Soal nomor 3 (Topik Persamaan dan Fungsi)}




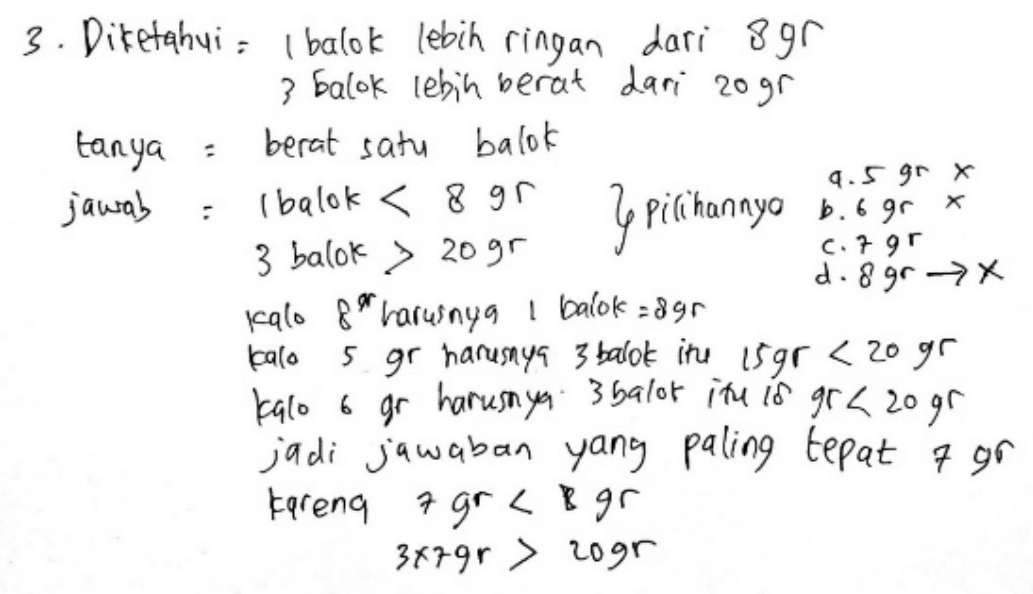

Gambar 10. Hasil jawaban subjek S1 dalam menjawab soal nomor 3

3. Diket: 3 logam balok, masing 2 Galok samo.

Ketika menimbang satu balok thdp berat $8 \mathrm{gr}$, balok terlihat lebih ringan dari $8 \mathrm{gr}$. tiga balok thdp berat $20 \mathrm{gr}_{i}$ balke terlitat lebih berat dari $20 \mathrm{gr}$.

Ditanya: Mana dari pilithan berikut yg bisa menyatakan berat 1 logain balok?

Jawab: $a \cdot 5 \mathrm{gr} \times 3=15 \mathrm{gr} \angle 20 \mathrm{gr}$

b. $6 \mathrm{gr} \times 3=18 \mathrm{gr} \angle 20 \mathrm{gr}$

c. $7 \mathrm{gr} \times 3=21 \mathrm{gr}>20 \mathrm{gr}$

d. $8 \mathrm{gr} \times 3=24 \mathrm{gr}>20 \mathrm{gr}$ tapi satu balok \& seharusnua seimbang dg timbangan

Jadi, jawaban yg tepat $=7 \mathrm{gr}$ (c)

Gambar 11. Hasil jawaban subjek S2 dalam menjawab soal nomor 3

3 Diket $=1$ balok $<8$ gram

3 balok $>20$ gram

Ditanya =berat i balok?



Gambar 12. Hasil jawaban subjek S3 dalam menjawab soal nomor

Pada topik persamaan dan fungsi, Subjek S1 dan S2 telah melakukan tahap identifikasi masalah, tahap menentukan tujuan dan tahap melaksanakan strategi. Keduanya tidak melakukan tahap mengeksplorasi strategi dan tahap melihat dan belajar. Subjek S3 telah melakukan tahap identifikasi masalah, tahap menentukan tujuan dan tahap melaksanakan strategi, serta tahap melihat dan belajar. Subjek S3 tidak melakukan tahap mengeksplorasi strategi. 


\section{Pembahasan}

Subjek dalam penelitian ini diambil sebanyak tiga siswa kelas VIII dengan 3 soal yang diberikan kepada subjek mengenai soal TIMSS konten aljabar. Sebelum digunakan, soal tersebut divalidasi oleh satu orang dosen Pendidikan Matematika Universitas Kristen Satya Wacana, yaitu Danang Setyadi, M.Pd., dan satu orang guru SMP Kristen 2 Salatiga sebagai praktisi lapangan yaitu Endang Budiastuti, S.Pd. Validasi soal penelitian ini bertujuan agar instrumen yang digunakan dalam penelitian ini dapat dinyatakan valid. Berikut merupakan hasil pengumpulan data penelitian subjek S1, S2, dan S3 terkait dengan pemecahan masalah siswa berdasarkan tahapan ideal dalam menyelesaikan soal TIMSS konten aljabar.

\section{A. Pembahasan nomor 1 (Topik Pola)}

Subjek S1, S2, dan S3 telah melaksanakan tahap identifikasi masalah. Kemampuan identifikasi semua subjek terlihat dari hasil wawancara, subjek mampu mengidentifikasi serta menjelaskan informasi dan masalah pada soal secara terperinci.

\begin{tabular}{|ll|}
\hline P : & Jadi apa masalah inti dari soal tersebut? \\
S1 : & Kalau perseginya ukuran 9x9 berapa jumlah ubin \\
& hitam dan jumlah ubin merah
\end{tabular}

Transkrip wawancara S1 dalam menjelaskan masalah utama dari soal nomor 1

\begin{tabular}{|ll|}
\hline P : Jadi sebenarnya apa masalah inti dari soal yang \\
perlu dicari solusinya? \\
S2 : Kita disuruh mencari ubin hitam dan ubin merah
\end{tabular}

Transkrip wawancara S2 dalam menjelaskan masalah utama dari soal nomor 1

$\mathrm{P}$ : Apa masalah inti dari soal tersebut?

S3 : Berapa banyak ubin hitam dan berapa banyak ubin merah dalam bentuk 9x9

Transkrip wawancara S3 dalam menjelaskan masalah utama dari soal nomor 1
Pada tahap yang kedua yaitu tahap menentukan tujuan, semua subjek mampu menentukan cara penyelesaian masalah yang akan digunakan. Subjek S1, S2, dan S3 mampu menjelaskan secara lisan rencana penyelesaian yang akan mereka lakukan saat diwawancara. Semua subjek belum berhasil melakukan tahap yang ketiga, yaitu tahap, mengeksplorasi strategi. Berdasarkan hasil wawancara semua subjek tidak melaksanakan tahap mengeksplorasi yang mungkin, karena semua subjek tidak menggunakan rumus pada materi yang pernah di pelajari sebelumnya. Subjek S3 tidak mengeksplorasi strategi atau mencari cara penyelesaian masalah lainnya untuk memecahkan soal nomor 1. Tahap yang keempat, yaitu tahap melaksanakan strategi. Semua subjek telah melakukan tahap melaksanakan strategi yang terlihat dari gambar 2, 3 dan 4. Pada tahap kelima, yaitu tahap melihat dan belajar, tidak dilakukan oleh subjek S1 dan S2, namun telah dilaksanakan oleh subjek S3. Subjek S1 dan S2 tidak melakukan tahap ini, dikarenakan subjek S1 dan S2 sudah yakin dengan jawaban yang dimilikinya. Hal tersebut didapatkan oleh peneliti saat melakukan wawancara dengan subjek S1 dan S2. Subjek S3 telah melakukan tahap melihat dan belajar. Subjek S3 menjelaskan secara lisan saat di wawancara bahwa subjek telah melakukan pengecekan ulang dengan cara menghitung ulang dan melihat pada pilihan ganda.

\section{B. Pembahasan Nomor 2 (Bentuk Aljabar)}

Semua subjek telah melaksanakan tahap identifikasi masalah. Kemampuan 
identifikasi semua subjek terlihat dari jawaban subjek S1, S2, dan S3 yang mampu mengidentifikasi serta menuliskan informasi dan masalah pada soal. Pada tahap yang kedua yaitu tahap menentukan tujuan, semua subjek mampu menentukan cara penyelesaian masalah yang akan digunakan. Semua subjek mampu menjelaskan secara terperinci mengenai rencana penyelesaian yang akan mereka lakukan. Subjek S1, S2, dan $\mathrm{S} 3$, belum berhasil melakukan tahap yang ketiga, yaitu tahap mengeksplorasi strategi. Berdasarkan wawancara yang telah dilakukan, semua subjek tidak melaksanakan tahap mengeksplorasi yang mungkin. Hal ini dikarenakan semua subjek tidak mengeksplorasi strategi atau mencari cara penyelesaian masalah lainnya untuk memecahkan soal nomor 2. Tahap yang keempat, yaitu tahap melaksanakan strategi. Semua subjek telah melakukan tahap melaksanakan strategi yang terlihat pada gambar 6, 7 dan 8. Pada tahap kelima, yaitu tahap melihat dan belajar. Subjek S1, S2, dan S3 tidak melakukan tahap ini, dikarenakan semua subjek sudah yakin dengan jawaban yang dimilikinya. Hal tersebut didapatkan oleh peneliti saat melakukan wawancara dengan subjek S1, S2, dan S3.

\section{Pembahasan Soal Nomor 3 (Topik Persamaan dan Fungsi)}

Subjek S1, S2, dan S3 telah melaksanakan tahap yang pertama, yaitu tahap identifikasi masalah. Berdasarkan wawancara peneliti dengan semua subjek dapat mengidentifikasi serta menjelaskan informasi dan masalah pada soal. Pada tahap yang kedua yaitu tahap menentukan tujuan, semua subjek mampu menentukan cara penyelesaian masalah yang akan digunakan. Subjek S1, S2, dan S3 mampu menuliskan secara terperinci dalam menunjukkan tujuan dalam soal nomor 3 . Semua subjek belum berhasil melakukan tahap yang ketiga, yaitu tahap mengeksplorasi strategi secara lisan saat diwawancara. Subjek S1, S2, S3 tidak melaksanakan tahap mengeksplorasi yang mungkin, karena semua subjek tidak menggunakan rumus pada materi yang pernah di pelajari sebelumnya dan tidak mengeksplorasi strategi atau mencari cara penyelesaian masalah lainnya untuk memecahkan soal nomor 3. Tahap yang keempat, yaitu tahap melaksanakan strategi. Semua subjek telah melakukan tahap melaksanakan strategi yang terlihat dari gambar 10, 11 dan 12. Pada tahap kelima, yaitu tahap melihat dan belajar, tidak dilakukan oleh subjek S1 dan S2, namun telah dilaksanakan oleh subjek S3. Subjek S1 dan S2 tidak melakukan tahap ini, dikarenakan subjek S1 dan S2 sudah yakin dengan jawaban yang dimilikinya. Hal tersebut didapatkan oleh peneliti saat melakukan wawancara dengan subjek S1 dan S2. Subjek S3 telah melakukan tahap melihat dan belajar. Subjek S3 melakukan pengecekan ulang dengan cara menghitung ulang dan mencoba satupersatu memasukkan jawaban pada pilihan ganda. seperti yang dijelaskan oleh subjek S3 saat diwawancara.

Terkait pembahasan di atas, berikut ini adalah tabel pemecahan masalah S1, S2, S3 dalam menyelesaikan soal TIMSS konten aljabar. 
Tabel 1. Profil Pemecahan Masalah Subjek

\begin{tabular}{|c|c|c|c|c|c|c|c|c|c|c|}
\hline \multirow{3}{*}{ Tahapan } & \multirow{3}{*}{ Indikator } & \multirow{2}{*}{\multicolumn{3}{|c|}{$\begin{array}{c}\text { Nomor } 1 \\
\text { Subjek }\end{array}$}} & \multirow{2}{*}{\multicolumn{3}{|c|}{$\begin{array}{c}\text { Nomor } 2 \\
\text { Subjek }\end{array}$}} & \multirow{2}{*}{\multicolumn{3}{|c|}{$\begin{array}{c}\text { Nomor } 3 \\
\text { Subjek }\end{array}$}} \\
\hline & & & & & & & & & & \\
\hline & & S1 & S2 & S3 & S1 & S2 & S3 & S1 & S2 & S3 \\
\hline \multirow{2}{*}{$\begin{array}{l}\text { Identify } \\
\text { Problem }\end{array}$} & $\begin{array}{l}\text { Menyatakan apa yang diketahui dan di } \\
\text { tanyakan pada soal }\end{array}$ & $\sqrt{ }$ & $\sqrt{ }$ & $\sqrt{ }$ & $\sqrt{ }$ & $\sqrt{ }$ & $\sqrt{ }$ & $\sqrt{ }$ & $\sqrt{ }$ & $\sqrt{ }$ \\
\hline & $\begin{array}{l}\text { Menentukan masalah inti yang akan dicari } \\
\text { dari soal }\end{array}$ & $\sqrt{ }$ & $\sqrt{ }$ & $\sqrt{ }$ & $\sqrt{ }$ & $\sqrt{ }$ & $\sqrt{ }$ & $\sqrt{ }$ & $\sqrt{ }$ & $\sqrt{ }$ \\
\hline $\begin{array}{l}\text { Define } \\
\text { Goals }\end{array}$ & $\begin{array}{l}\text { Menentukan apa yang menjadi tujuan dari } \\
\text { soal }\end{array}$ & $\sqrt{ }$ & $\sqrt{ }$ & $\sqrt{ }$ & $\sqrt{ }$ & $\sqrt{ }$ & $\sqrt{ }$ & $\sqrt{ }$ & $\sqrt{ }$ & $\sqrt{ }$ \\
\hline \multirow{4}{*}{$\begin{array}{l}\text { Explore } \\
\text { possible } \\
\text { strategies }\end{array}$} & $\begin{array}{l}\text { Menyusun rencana penyelesaian yang akan } \\
\text { digunakan }\end{array}$ & $\sqrt{ }$ & $\sqrt{ }$ & $\sqrt{ }$ & $\sqrt{ }$ & $\sqrt{ }$ & $\sqrt{ }$ & $\sqrt{ }$ & $\sqrt{ }$ & $\sqrt{ }$ \\
\hline & $\begin{array}{l}\text { Mengaitkan rumus atau materi yang telah } \\
\text { dipelajari sebelumnya }\end{array}$ & - & - & - & $\sqrt{ }$ & $\sqrt{ }$ & $\sqrt{ }$ & - & - & - \\
\hline & $\begin{array}{l}\text { Mengeksplorasi strategi/mencari alternatif } \\
\text { cara lain yang dapat digunakan dalam } \\
\text { menyelesaikan masalah }\end{array}$ & $\sqrt{ }$ & $\sqrt{ }$ & - & - & - & - & - & - & - \\
\hline & $\begin{array}{l}\text { Menentukan salah satu langkah yang dapat } \\
\text { digunakan untuk menyelesaikan masalah } \\
\text { dari soal tersebut }\end{array}$ & $\sqrt{ }$ & $\sqrt{ }$ & $\sqrt{ }$ & $\sqrt{ }$ & $\sqrt{ }$ & $\sqrt{ }$ & $\sqrt{ }$ & $\sqrt{ }$ & $\sqrt{ }$ \\
\hline $\begin{array}{l}\text { Anticipate } \\
\text { outcomes } \\
\text { and act }\end{array}$ & $\begin{array}{l}\text { Melaksanakan penyelesaian masalah } \\
\text { secara runtut dan bertahap }\end{array}$ & $\sqrt{ }$ & $\sqrt{ }$ & $\sqrt{ }$ & $\sqrt{ }$ & $\sqrt{ }$ & $\sqrt{ }$ & $\sqrt{ }$ & $\sqrt{ }$ & $\sqrt{ }$ \\
\hline $\begin{array}{l}\text { Look and } \\
\text { Learning }\end{array}$ & $\begin{array}{l}\text { Melihat kembali atau mengevaluasi apakah } \\
\text { tahap-tahap penyelesaian sudah sesuai } \\
\text { dengan rencana awal }\end{array}$ & - & - & $\sqrt{ }$ & - & - & - & - & - & $\sqrt{ }$ \\
\hline
\end{tabular}

Berdasarkan tabel di atas, analisis terhadap ketiga subjek dilakukan berdasarkan hasil tes dan wawancara. Sejalan dengan Annizar (2015) yang menyatakan bahwa pemecahan masalah IDEAL yaitu merencanakan dan melaksanakan strategi guna memecahkan permasalahan yang diberikan. Subjek mampu mengidentifikasi masalah, namun subjek belum mampu menuliskan informasi yang di dapat dari soal tersebut ke dalam Bahasa matematika (Ulya, 2016).

\section{Simpulan dan Saran}

\section{Simpulan}

Berdasarkan penelitian yang telah dilakukan pada siswa berkemampuan tinggi pada kelas VIII C SMP Kristen 2 Salatiga yang telah mempelajari materi Aljabar, dapat 
disimpulkan bahwa siswa mampu menyelesaikan masalah yang diberikan, namun belum sesuai dengan seluruh tahapan yang ada pada pemecahan masalah IDEAL. Siswa belum sepenuhnya mampu menerapkan tahap mengeksplorasi strategi, namun sudah mampu menerapkan tahap identifikasi masalah, tahap menentukan tujuan, tahap melaksanakan strategi, serta tahap melihat dan belajar.

\section{Saran}

Guru diharapkan dapat menstimulasi penalaran dan pemahaman siswa sebagai kemampuan awal yang dapat digunakan untuk mengonstruksi pengetahuan yang dapat digunakan untuk mengonstruksi pengetahuan yang dapat digunakan sebagai landasan eksplorasi suatu masalah.

Adapun saran untuk peneliti lain, penelitian ini dapat dijadikan sebagai acuan bagi peneliti - peneliti selanjutnya yang mempunyai relevansi dalam variabel-variabelnya. Kekurangan dan keterbatasan dalam penelitian ini hendaknya dapat digunakan sebagai pembelajaran untuk penelitian yang lebih baik.

\section{Daftar Pustaka}

Annizar, A. M. (2015). Analisis Kemampuan Pemecahan Masalah Soal PISA Menggunakan Model IDEAL Pada Siswa Usia 15 Tahun di SMA Nuris Jember. Universitas Jember. Diakses Tanggal 26 Juli $2019 \quad$ Dari Http://Repository.Unej.Ac.Id/Handle/12 3456789/73118.
Bransford, J. D., \& Stein, B. S. (1984). The ideal problem solver: a guide for improving thinking, learning, and creativity (2nd ed.). New York: W.H Freeman.

Cahyono, B., \& Adilah, N. (2016). Analisis Soal Dalam Buku Siswa Matematika Kurikulum 2013 Kelas VIII Semester I Berdasarkan Dimensi Kognitif Dari TIMSS. JRPM (Jurnal Review Pembelajaran Matematika, 1(1), 86-98.

Dahar, R. W. (1989). Teori-teori belajar. Jakarta: Penerbit Erlangga.

Damayanti, E. R., \& Yunianta, T. N. H. (2018). The Profile Of Junior High School Students'problem Solving In Answering The Content Pisa Test Of Uncertainty And Data Based On Ideal Problem Solving. MaPan: Jurnal Matematika Dan Pembelajaran, 6(2), 250-264.

Nayazik, A. (2017). Pembentukan Keterampilan Pemecahan Masalah melalui Model IDEAL Problem Solving dengan Teori Pemrosesan Informasi. Kreano, Jurnal Matematika KreatifInovatif, 8(2), 182-190.

Purnomo, E. A., \& Mawarsari, V. D. (2014). Peningkatan Kemampuan Pemecahan Masalah Melalui Model Pembelajaran IDEAL Problem Solving Berbasis Project Based Learning. Jurnal Karya Pendidikan Matematika, 1(1).

Rudhito, M. A., \& Prasetyo, D. A. B. (2016). Pengembangan Soal Matematika Model TIMSS Untuk Mendukung Pembelajaran Matematika SMP Kelas VII Kurikulum 2013. Jurnal Cakrawala Pendidikan, 35(1), 88-97.

Sidauruk, E. E. V., \& Ratu, N. (2018). 
Deskripsi Pemecahan Masalah Siswa Smp Dalam Menyelesaikan Soal TIMSS Konten Aljabar. Jurnal Karya Pendidikan Matematika, 5(2), 28-37.

Sugiyono. (2015). Metode Penelitian Kuantitatif, Kualitatif, dan $R \& D$. Bandung: Alfabeta.

Susanti, E. (2016). Pengembangan Soal Matematika Tipe TIMSS Menggunakan Konteks Rumah Adat Untuk Siswa Sekolah Menengah Pertama. Jurnal Pendidikan Matematika, 10(2), 1-22.

Susiana, E. (2010). IDEAL Problem Solving dalam Pembelajaran Matematika. Kreano, Jurnal Matematika KreatifInovatif, 1(2), 73-82.
Ulya, H. (2016). Profil Kemampuan Pemecahan Masalah Siswa Bermotivasi Belajar Tinggi Berdasarkan IDEAL Problem Solving. Jurnal Konseling Gusjigang, 2(1), 90-96.

Widayanti, E., \& Kolbi, I. A. (2018). Analisis Kesalahan Siswa Dalam Mengerjakan Soal TIMSS Untuk Kategori Penalaran. Jurnal Review Pembelajaran Matematika, 3(1), 76-85.

Yanti, A. P., \& Syazali, M. (2016). Analisis Proses Berpikir Siswa dalam Memecahkan Masalah Matematika Berdasarkan Langkah-Langkah Bransford dan Stein Ditinjau dari Adversity Quotient. Al-Jabar: Jurnal Pendidikan Matematika, 7(1), 63-74. 